\title{
SISTEMA DA VERDADE (APRESENTADA) E UNIVERSO DA DÚVIDA
}

\section{SYSTEM OF TRUTH (PRESENTED) AND THE UNIVERSE OF DOUBT}

Sérgio Adriano Dias Luiz 


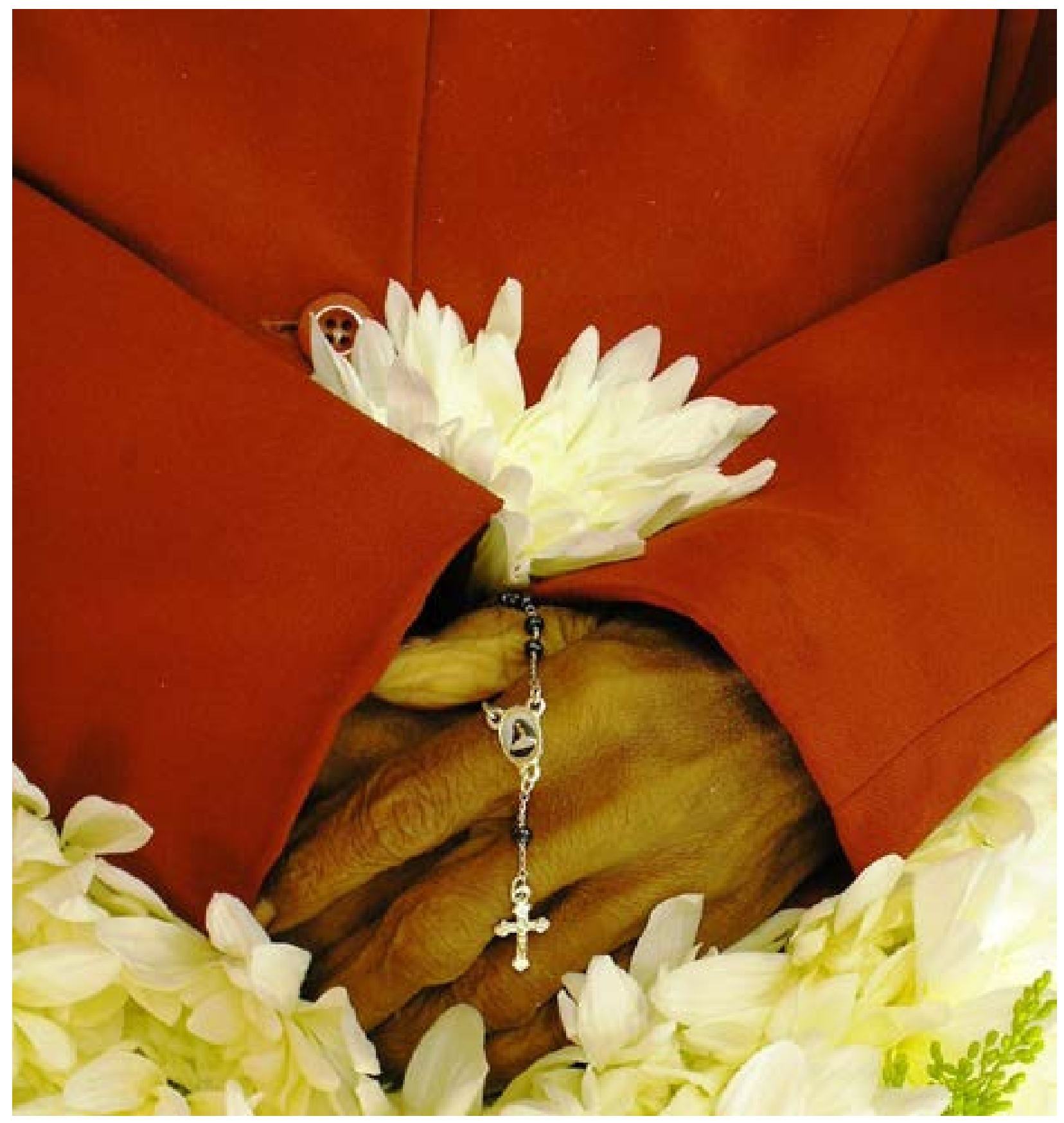

Sérgio Adriano $\mathrm{H}$

Portador da verdade II | 2006 | Fotografia | 6 × $9 \mathrm{~cm}$ | Acervo do artista. 


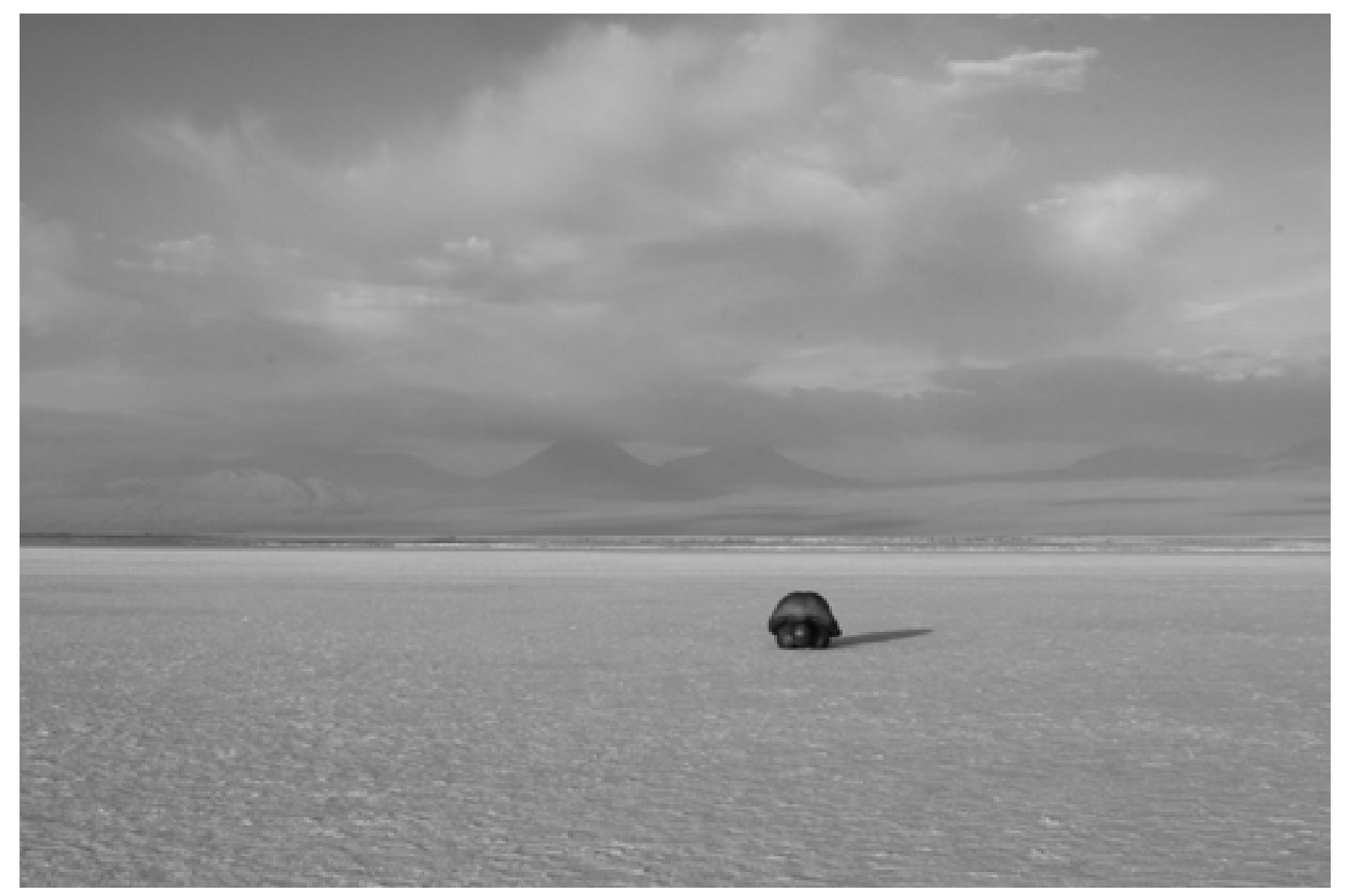

Sérgio Adriano H | Entre o conhecimento e da verdade | 2014 | Fotografia em tecido | $200 \times 300 \mathrm{~cm} \mathrm{|} \mathrm{1/3} \mathrm{|Acervo} \mathrm{do} \mathrm{artista}$ 


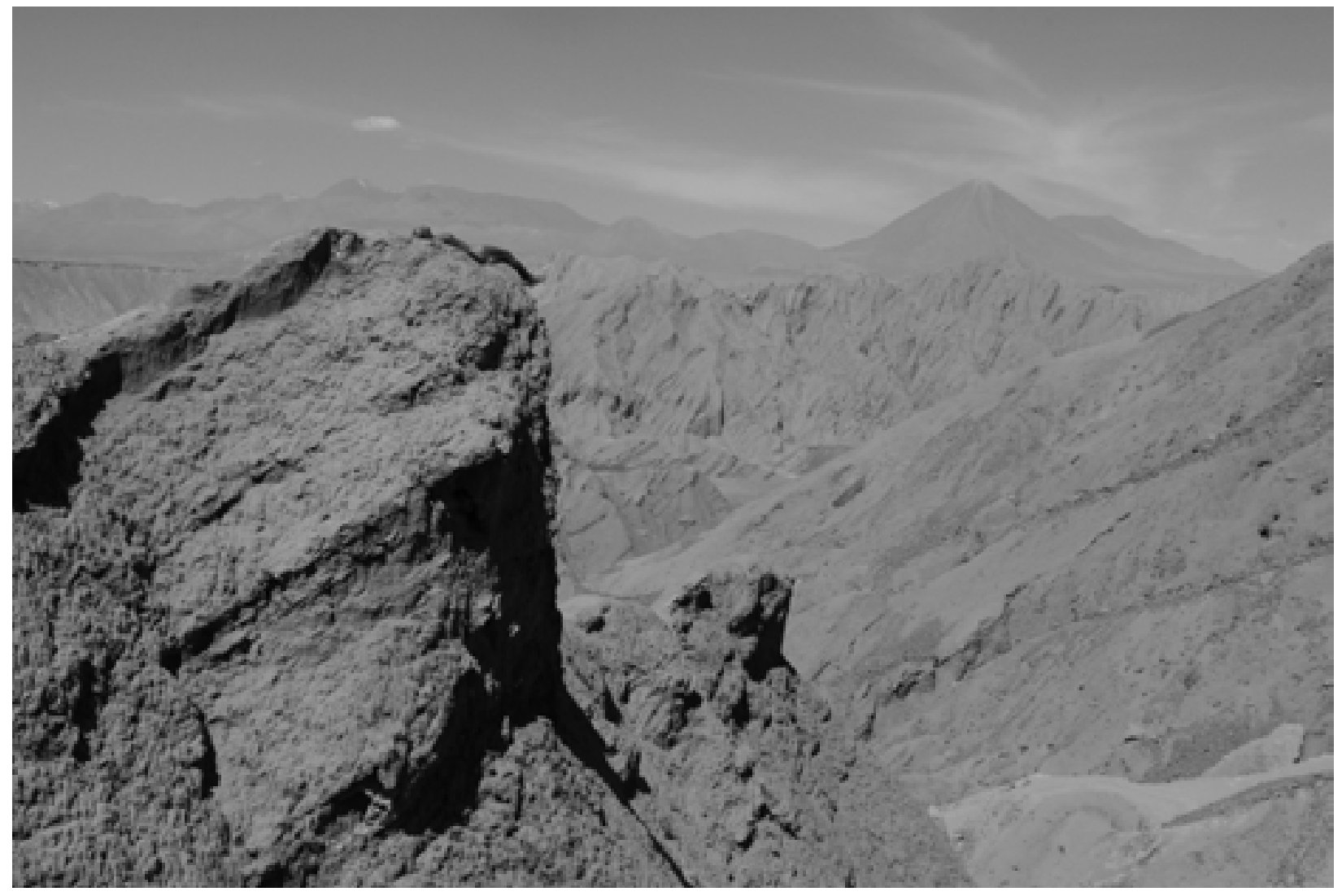

Sérgio Adriano H | Entre a aparência e a distinção | 2014 | Fotografia | 1 fotografia 67 X $100 \mathrm{~cm}$ | 1/3 |Acervo do artista
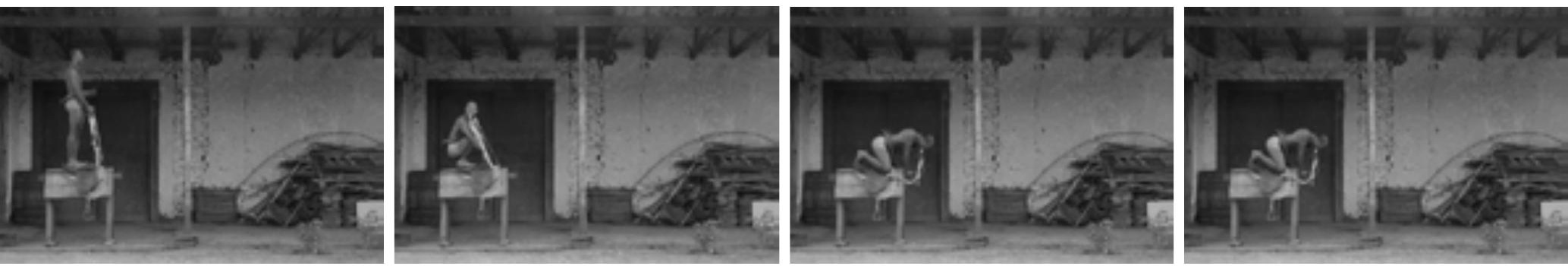

Sérgio Adriano H | Diligência |2014 | Fotografia | 4 fotografias 67 X $100 \mathrm{~cm}$ cada Total: 67 x $520 \mathrm{~cm}$ | 1/3 |Acervo do artista 


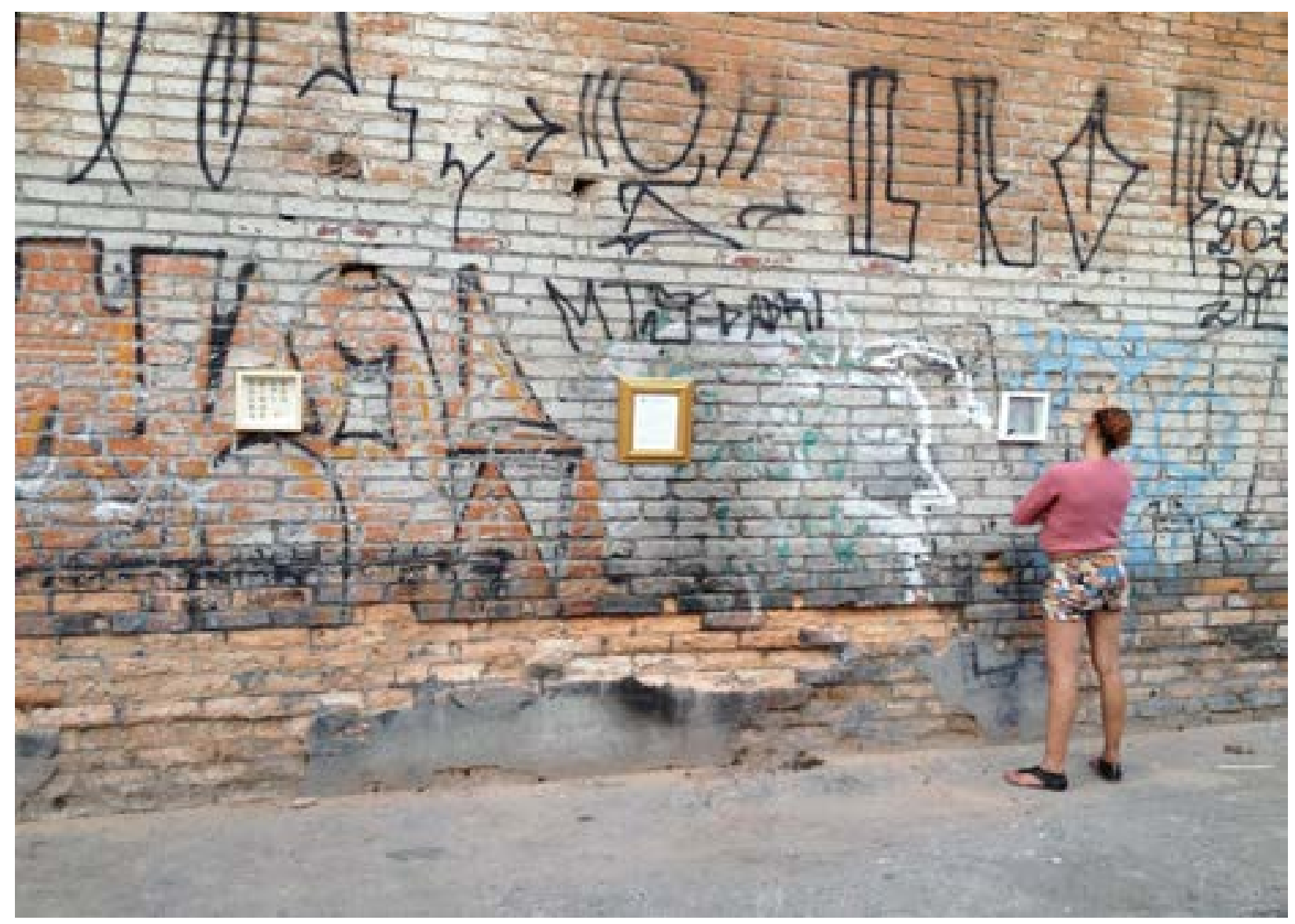

Registro de Ação | Brás | São Paulo | Brasil

Sérgio Adriano H | Verdade 1000 vezes repetida se torna verdade | 2014 | Ação/Exposição. Dimensões variadas
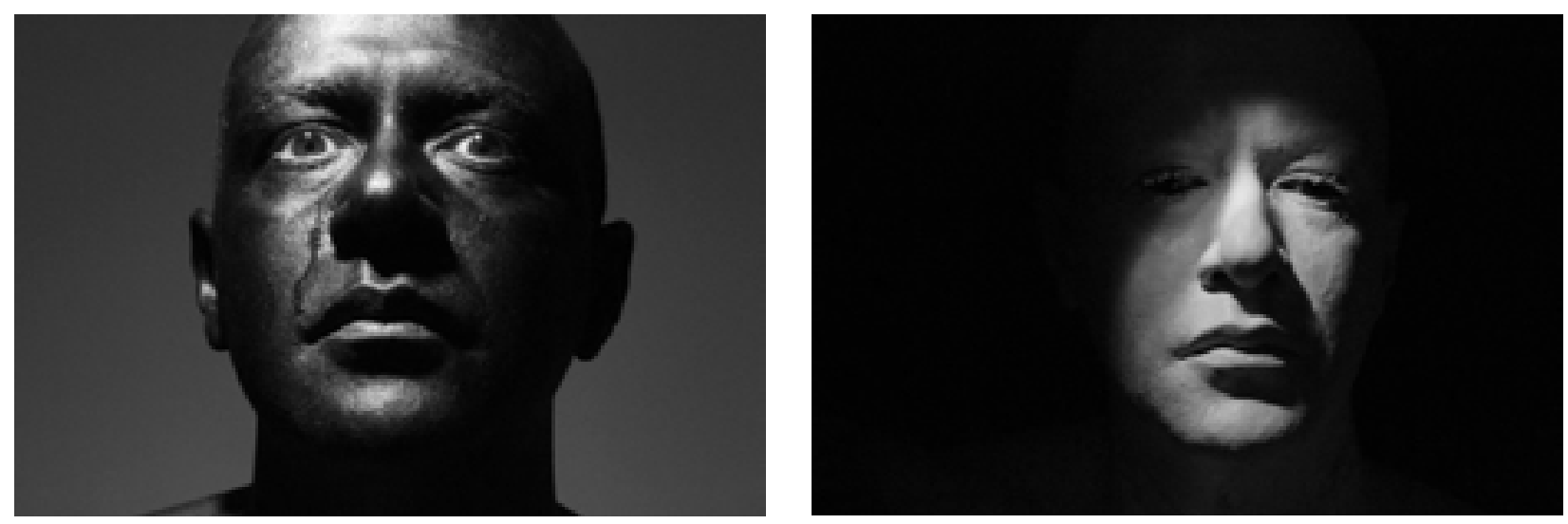

Sérgio Adriano H | Preto de alma branca | 2013 |Fotografia | 100 x $67 \mathrm{~cm}$. Branco de alma preta | 2013| Fotografia | 100 x $67 \mathrm{~cm}$ |Acervo do artista |j Realizado com recursos da Lei de Incentivo a Cultura de Joinville Sindecii 


\section{Resumo}

O processo criativo de Sérgio Adriano $\mathrm{H}$ se fundamenta em pesquisas teóricas e práticas acerca dos fluxos de informações na sociedade contemporânea. A pesquisa sobre a "verdade" iniciou no ano de 2003 tendo a morte como objeto principal de estudo, passou por constantes transformações visuais e teóricas. No ano de 2013, a pesquisa, ainda voltada para o que "É a Verdade", é tomada por um novo olhar: não deveria buscar somente o que "É a Verdade", mas compreender como o "Sistema da Verdade" opera no indivíduo e rege a si mesmo. Os novos estudos levam ao encontro da relação entre Verdade, Felicidade e Sociedade, que resultaram em vasta produção artística. O objetivo da pesquisa é discutir a estrutura do Sistema da Verdade (Apresentada) e Universo da Dúvida.

Palavras-chave: Arte - Sociedade Verdade - Felicidade - Sabedoria

\section{Abstract}

Sérgio Adriano $\mathrm{H}$ creative process is based on theoretical and practical research over the information flows in the contemporary society. The research theme "truth" started in year 2003 with "death" as the main object of study and was constantly transformed visually and theoretically since then. In year 2013, the research still focused on what "is the Truth", took a new approach: should not only seek for what "is the truth" but understand how the "System of Truth" operates and governs the individuals themselves. New studies drive to the meeting of the relationship between Truth, Happiness and Society, resulting in extensive artistic production. The objective of the research is to discuss the structure of the presented "System of Truth" and the "Universe of Doubt".

Keywords: Art - Society - Truth Happiness - Wisdom

ISSN: 2175-2346 
Meu processo criativo se fundamenta em pesquisas teóricas e práticas acerca dos fluxos de informações na sociedade contemporânea. A pesquisa sobre a "verdade" iniciou no ano de 2003 tendo a morte como objeto principal de estudo, passou por constantes transformações visuais e teóricas. Fato relevante na trajetória do artista, o falecimento de sua mãe, Diva, em 2006, impactou seu processo criativo desde então. Com formação religiosa e embasada em suas crenças, ela acreditava que o corpo de uma pessoa morta deveria ser velado um dia e uma noite inteira, não importando a hora de seu falecimento.

Esse fato, em sua perspectiva ritualística, leva o artista, no velório de sua mãe, a realizar uma série de fotografias de detalhes sutis da morte com o título: "Portador da Verdade". A obra repercute e reverbera o tema inicial sobre a morte, ampliando-o para debates e pesquisas direcionados para o que "é a verdade". No ano de 2013, a pesquisa, ainda voltada para o que "É a Verdade", é tomada por um novo olhar: não deveria buscar somente o que "É a Verdade", mas compreender como o "Sistema da Verdade" opera no indivíduo e rege a si mesmo. Os novos estudos levam ao encontro da relação entre Verdade, Felicidade e Sociedade, que resultaram em vasta produção artística.

No decorrer da vida o homem é apresentado a diversas verdades - Verdades Apresentadas - que irão constituir o - Eu Verdade Apresentada. Dentro desse Sistema da Verdade Apresentada o Eu Verdade Apresentada, confrontado com os Dados do Sistema da Verdade Apresentada (crenças e hábitos), verifica a Verdade Apresentada e com isso busca e pontua o que é - Aparência e Distinção. A Dúvida versus o Eu Apresentado forma o Eu Dúvida que faz parte do Universo da Dúvida. Este universo é constituído da Dúvida mais Conhecimento versus Confronto no que gera a Verdade. Portanto, o Universo da Dúvida é a capacidade da Dúvida sobre o Sistema da Verdade Apresentada. Forma-se aí o Sistema da Dúvida.

O objetivo da pesquisa não é descobrir o que é A Verdade, mas sim, como o Sistema da Verdade Apresentada e o Sistema da Dúvida operam sobre o indivíduo. Desta forma, somente o Conhecimento pode superar esta Verdade Apresentada, transformando-se em uma oportunidade de duvidar, ou seja, dar o benefício da dúvida sobre algo que foi apresentado como verdade. Não é simplesmente duvidar por duvidar; é duvidar para uma elevação de conhecimento. Ora, "A Dúvida é o começo da sabedoria"1. A verdade para ser a Verdade, não depende de outros fatores, e por ser Verdade é que o Homem deve almejá-la.

Projetos/Pesquisa: A Dúvida da Verdade. O projeto estruturado em três etapas iniciadas em fevereiro de 2014 consistiu em ações realizadas no deserto do Atacama e na cidade de São Paulo, onde insiro o meu próprio corpo nu na paisagem e realizo a fotografia digital via controle remoto, para depois confrontar essas duas realidades e assim montar ações/exposições a partir desse estudo. A escolha do enquadramento, da abertura e da velocidade do obturador, mais a posição em que meu corpo é inserido na paisagem e na arquitetura da sombra, como também o conceito curatorial da ação/ exposição, se dá em função da busca da produção de uma Verdade Apresentada que após confrontada gera o Universo da Dúvida. Neste contexto, "O real é aquilo que não é o que eventualmente dele pensamos, mas que permanece não afetado pelo que dele 1 Ségur 
possamos pensar"2.

"Diligência": Ação realizada no período de residência como artista na Curatoría Forense Residências de Arte Contemporânea, Villa Alegre, Chile, 12 à 23 de fevereiro 2014.A palavra diligência vem do verbo latim diligere, que significa amar; diligens (diligente) significa aquele que ama. No dicionário existem determinadas definições, que podem ser consideradas como procura, investigação, pesquisa, busca. Desta forma, uma busca humana por um desejo almejado. Segundo Boyer, é pela razão que o homem obtém o conhecimento, pela razão que consegue guiar sua vida. Buscar conhecer é, antes de tudo, buscar o objeto cujo encontro apaziguará nosso apetite de conhecer e, por isso, estabelecer nosso estado de beatitude ${ }^{3}$.

A primeira e, em um sentido, a única regra da razão, é aquela de que a fim de aprender, você deve desejar aprender, e com tal desejo não se satisfazer com o que você já se inclina pensar, seguindo-se um corolário que é digno de ser inscrito em todos os muros da cidade da filosofia: Não bloqueie o caminho da investigação ${ }^{4}$.

Minhas imagens carregam um Vazio que solicita novas experiências e novos pensamentos. Um desejo de levar o espectador a lugares que o mesmo nunca esteve ou o receptor levar o artista a um lugar que ele nunca imaginou e, a descoberta de um Outro pensado no interior de si Mesmo.O que é a imagem como experiência? É a não imagem, pois se for imagem não gera o pensamento. É o impensado que formula novos pensamentos que por meio da investigação codifica a imagem e faz brotar o conhecido $^{5}$. A imagem produzida é um meio para se chegar a um pensamento e sensação antes impensado(a). Por ser impensado(a) não tem relação com o velho, já que não existe o antes mas somente o próximo, portanto, não há regras de conduta do sentir, do pensamento, o que se estabelece então o novo.

"Verdade 1000 vezes repetida se torna verdade": O projeto é composto de uma Ação/Exposições de arte em tapumes, muros, calçadas e escadarias nos espaços públicos locais, onde o invisível esteja presente, isto é, espaços que não estão inseridos no universo cultural e à sombra da sociedade. A Ação/Exposição é composta por 38 fotografias de Sérgio Adriano $\mathrm{H}$, colocadas em molduras de $20 \times 20 \mathrm{~cm}, 30 \times 30 \mathrm{~cm}$, $30 \times 40 \mathrm{~cm}$ e 3 livros com as páginas coladas. O transporte é feito com 1 carrinho de duas rodas e 6 malas e o deslocamento acontece pelo caminhar, metrô, ou transporte público. Tendo como proposta realizar esta Ação/Exposição 1000 vezes em diversos locais do mundo. A duração da Exposição/Ação em media é de 4 horas e com a permanência do artista que dialoga com o público. A escolha do local é baseada na grande circulação de pessoas, na importância histórica e por ser considerado em alguns casos, um ponto estratégico para o inesperado encontro com uma exposição de arte.

Segundo Marilena Chauí "do verbo facio, fazer uma ação, deriva-se o verbo afficio, receber uma ação, de maneira que o primeiro traço da affectio é a passividade, o sofrer uma ação originada em outra coisa". Dentro desse contexto é que a palavra ação é empregada na produção do artista, que realiza uma "Ação" que reverbera no

$2 \quad$ IBRI, Ivo Assad. Kósmos Noetós: a arquitetura metafísica de Charles S. Peirce. Charles S. Peirce - Collected Papers (8.12)

3 BOYER, Charles S. J. L'idée de Vérité Dans La Philosophie de Saint Augustin, 1939, p. 224.

$4 \quad$ IBRI, Ivo Assad. Kósmos Noetós: a arquitetura metafísica de Charles S. Peirce, 1992, p. 69.

5 FERRERA, Lucrecia D'Aléssio. Leitura sem Palavras, 2000, p.31. 
espectador, onde o mesmo, saindo da condição de espectador (passividade), se torna um agente de uma nova "Ação". Quando estou em no meu estúdio e visualizo minha produção, começo a viver, e ao levar para as ruas minhas obras, meu corpo, minha alma, busco a dialogar com os espectadores nas diversas linguagens artísticas. Neste momento estou vivendo plenamente. Isto fica mais latente quando existe uma interação do público, enriquecendo meu repertório como artista e pessoa. O imaginário artístico e social revela muitas coisas, que nem sabíamos que era segredo para nós, o quanto da realidade se torna presente em uma exposição, logo, é o questionamento da sociedade, um meio de conexão, um dispositivo no campo público que faz completar a proposta "Verdade 1000 vezes repetida se torna verdade".

Os questionamentos sobre a Verdade, Felicidade e Sociedade, levam a uma grande oportunidade de reflexão sobre o Ser e o Outro, ou seja, o material se torna imaterial, feito de ideias. O papel do artista é tão importante que é capaz de modificar a maneira como olhamos o mundo a nossa volta. Também a interação do público, do observador, tem seu papel fundamental, pois sem o mesmo a beleza das ideias não se transpõe para o cotidiano. Basicamente, nesta obra, utilizo dois métodos: Trabalho com cruzamentos de linguagens: instalações, objetos, fotografias, imagens, palavras, ideias que provocam um diálogo produtivo e reflexivo; Abordo os processos sociais que definem regras de aceitação, baseados no decorrer da vida onde o homem é apresentado a diversas verdades - Verdades Apresentadas - que irão constituir o - Eu Verdade Apresentada que é estipulado por Crenças e Hábitos.

"O Visível do Invisível": Em processo - ano 2016. Intervenção Urbana/Instalação/ Ação de Arte que se apropriará de muros, tapumes, abrigos, locais abandonados ou semiabandonados, composta por 12 fotografias da serie "Preto de Alma Branca" e "Branco de Alma Preta", no tamanho de $80 \mathrm{~cm} \mathrm{X} 120 \mathrm{~cm}$, em impressão fotográfica sobre PVC. Cada Ação é composta por quatro horas de duração com uma palestra/ bate-papo com as pessoas que circulam no local.

A série "Preto de Alma Branca" e "Branco de Alma Preta" são registros fotográficos de uma Ação isolada realiza no ano 2013 em meu estúdio, onde pinto o próprio rosto de branco, na sequencia choro lágrimas pretas. Em uma segunda Ação, com o rosto pintado de preto choro lágrimas brancas. A composição da iluminação completa a atmosfera da obra fotográfica, uma analogia ao isolamento da dor do preconceito, dor da dor. Busco o diálogo com o espectador, com a comunidade, com os estudantes, sobre a igualdade entre os homens, tornando visível o que está invisível, uma análise sobre "sabedoria populares" ou "ditos populares", características do invisível. Exponho em muros meu olhar sobre $O$ Visível do Invisível abordando o cenário social, político, econômico, no debate sobre o Negro na sociedade. Um interagir, um interagir sobre o que não se deseja olhar, uma morte social através do preconceito, morte que não é apenas física, mas moral e diária7.

O preconceito, o racismo, é invisível, somente é sentido e visível pelo atingido, pela pessoa em questão. Invisível para muitos, visível para todos os negros que não estão dentro do estereótipo de uma sociedade banalizada por questões de beleza e cor 6 CHAUI, Marilena. Introdução à história da filosofia: as escolas helenísticas, volume II, 2010, p. 248.

7 Segundo uma pesquisa realizada pela Universidade de Michigan nos Estados Unidos, a desigualdade racial é evidente: para cada US\$ 6 com brancos, os negros têm US\$1, há 20 vezes mais condenações de negros em casos parecidos, 3 vezes mais expulsões escolares, percepção de tratamento injusto pela polícia, os negros são os que menos têm casa própria. Jornal Metro News. 21/08/14 
de pele. O racismo está embutido em falas habituais do cotidiano, "serviço de preto", "preto de alma branca", "branco de alma preta". O filosofo Franklin Leopoldo e Silva ressalta que "Singularidades raciais e culturais devem ser comparadas, para ressaltar o sentido da diversidade". Existirá um momento em que uma criança de 5 ou 6 anos de idade, voltando da escola para sua casa, não indagará mais seu pai, por que seu coleguinha de classe foi hostilizado, pois sua cor de pele é "negra", "preta", "amarela", "vermelha"?

A Arte e o Homem Sábio. A Arte possibilita nos mantermos vivos e lúcidos neste mundo que habitamos e para isso precisamos quebrar paradigmas sociais. Analisar e questionar como as regras são impostas e por quem. Muitas vezes, olhamos a arte como um 'perigo iminente', algo desconhecido e reagimos a este perigo pela falta de compreender o signo e a significância. Assim, por um ato involuntário de negação, perdemos o melhor que a Arte nos oferece: a experiência de um novo sentir de significados amplos; logo, o artista contribui para o diálogo sobre o signo e a significação, desmitificando a Arte $^{8}$.

A Arte se transforma com a evolução humana; os signos se modificam com as transformações da linguagem e a sociedade define seu representante de algo, o signo, que está por outra coisa. Esta ação do signo acende os conflitos, que em um determinado momento gera um espaço-tempo de sensação de vazio. Todo código é constituído de signos que criam sua própria sintaxe e maneira de representar, para decodificar qualquer sistema é necessário identificar o signo. Serão a decodificação e a percepção do signo que reestabelecerão a cognição?.

O signo se torna signo quando tem sentido para o outro, ou seja, quando é absorvido por outra pessoa, codificado, se tornando significativo. Um mesmo objeto condensa significado próprio a diferentes contextos de períodos da história cronológica, o qual se apresenta perante aos fatos culturais de diferentes maneiras, sendo que a cultura é constituída de sistemas de signos que articulam significados. Logo, a Arte é a articulação de significados, um exercício que se constrói na quebra das amarras de um olhar comum, na procura consciente da própria forma de olhar, no exercício de buscar novos paradigmas, na construção de relações e no olhar de um pensamento que pode ser divergente, questionador, levando a um pensar. A sensibilidade aumenta à medida que se entra em contato com a Arte e, cada contato que se estabelece, incorpora algo de novo à sensibilidade.

Precisamos transcender o ver para o olhar e o escutar para o ouvir, não fomos educados para olhar pensando o mundo, a realidade. E como consequência esse olhar cristalizado produziu uma cegueira estereotipada. Olhar envolve a atenção e é a mais alta forma de generosidade, pois envolve uma sintonia consigo mesmo e com o gru$\mathrm{po}^{10}$. O ver e o escutar fazem parte do processo de construção desse olhar, porém também não fomos educados para a escuta. Em geral, não ouvimos o que o outro fala, mas sim o que gostaríamos de ouvir. O mesmo acontece em relação ao olhar estereotipado, estático, imóvel, querendo ver só o que agrada, o que se sabe. Ver e ouvir de- 
manda entrega ao outro e só se entende o outro e sua história se houver uma abertura de aprendiz. "Ver não é o mesmo que olhar, assim como ouvir não é igual a escutar. Ver envolve apenas o esforço de abrir os olhos, olhar significa abrir a mente e usar o intelecto"11.

Assim, procuro, a partir da Arte, evocar aspectos do pensamento e indagações no que se refere à Verdade, à Felicidade, ao Erro, logo, Corpo, Palavra, Fé e Sociedade. Esta questão se desdobrará em outras indagações filosóficas, pois não basta responder apenas à indagações, é necessário também dar vazão a diversos outros questionamentos que se desenvolve sobre o prisma da Arte da Vida. Em determinados momentos, faço emergir questões que estão insinuadas, ainda que não plenamente abordadas, mas que são latentes no espectador. Neste postulado, amplio o olhar sobre o que é apresentado, onde o Falso é tomado pelo Verdadeiro, pela falta de conhecimento, e onde, cada vez mais, estamos mais informados, mas isso não representa ganho de conhecimento. ${ }^{12}$

O Homem sábio percebe que a Alma precisa ser tratada, assim como quando o corpo encontra-se enfermo, precisado de cuidados médicos, a alma precisa dos cuidados do próprio Homem sábio para obter a cura, como relata Chaui "a filosofia, que nos ensina curar-nos a nós mesmos. A doença do corpo exige o concurso de muitos outros para que a saúde seja recuperada, mas a alma precisa apenas de si mesma para curar-se, bastando que o queira"13. A doença da humanidade é reconhecer que não está doente. A pior doença da alma, não é ver como ela está, mas imaginar como ela gostaria de estar. O remédio para esta doença é um despertar da falsa consciência para a verdade, liberta-se para a consciência, e o ato de filosofar é a filosofia da cura da Alma. A verdade para ser a Verdade, não depende de outros fatores, e por ser Verdade é que o Homem deve almejá-la.

Com efeito, a tomada de consciência do homem sobre si mesmo leva ao conhecimento de sua existência. Não é a busca externa que o guia ao encontro da verdade e felicidade, mas a descoberta sobre si mesmo e sobre o outro, e, nesta descoberta, transforma-se em Homem Sábio. O desafio do Artista, não é aplainar o terreno, mas sim, assinalar com clareza os acidentes, as dificuldades, os desafios. Cabe ao artista se busca a sabedoria para si e para o outro, fazer com que os problemas aflorem, e não compor uma doutrina apaziguadora ${ }^{14}$. É esse repertório teórico que embasa a concepção e criação das obras apresentadas e que serve de sustentação para o processo das pesquisas em desenvolvimento que venho realizando.

\section{REFERÊNCIAS}

AGOSTINHO, Santo. Confissões. Tradução de J. Oliveira Santos, S.J., e A. Ambrósio de Pina, S.J.. Tradução José Américo Motta Pessanha. São Paulo: Abril Cultural, 1980. BOYER, Charles S. J. L'idée de Vérité Dans la Philosophie de Saint Augustin. Paris: Be-

\footnotetext{
11 CUMMING, Robert. Para Entender a Arte, 1996, p. 35.

12 AGOSTINHO, Santo. Confissões, V, 10.

13 CHAUI, Marilena. Introdução à história da filosofia: as escolas helenísticas, volume II, 2010,p. 317.

14 NOVAES, Moacyr. Linguagem e Verdade nas Confissões In: PALACIOS, Pelayo Moreno (Org.). Tempo e razão. 1600 anos das Confissões de Agostinho, 2002, p. 43.
} 
auchesne et ses fils, 1939.

CHAUI, Marilena. Introdução à história da filosofia: as escolas helenísticas, volume II. São Paulo: Companhia das Letras, 2010.

CUMMING, Robert. Para Entender a Arte. São Paulo: Ática, 1996.

EPSTEIN, Isaac. O Signo. 7.ed. São Paulo: Ática, 2000.

FERRERA, Lucrecia D'Aléssio. Leitura sem Palavras. 4. ed. São Paulo: Ática, 2000.

FREIRE, Madalena . Observação, registro e reflexão. Instrumentos Metodológicos I. $2^{a}$

ED. São Paulo : Espaço Pedagógico, 1996.

IBRI, Ivo Assad. Kósmos Noetós: a arquitetura metafísica de Charles S. Peirce. São Paulo: Perspectiva: Hólon, 1992.

WOOD, Paul. Arte Conceitual. São Paulo, Cosac \& Naify Edições, 2002.

Currículo artístico resumido: Sérgio Adriano H (Joinville/SC, 1975) artista visual, pesquisador e produtor cultural, vive, estuda e produz nas cidades de Joinville e São Paulo. Formado em Artes Visuais, Mestre em Filosofia (Faculdade de São Bento/SP - 2016), integra o Grupo P.S. com a artista Priscila dos Anjos e possui obras em acervos públicos e particulares. Em 2014, foi selecionado como um dos 30 artistas mais influentes do estado de Santa Catarina, tendo sua biografia incluída no livro "Construtores das Artes Visuais: Cinco Séculos de Artes em Santa Catarina". Ainda em 2014, na cidade de São Paulo, funda a Residência Artística Diva Base 44, com o propósito de acolhimento de artistas de varias nacionalidades objetivando resinificar o cotidiano e a cidade a partir da Arte. Possui mais de 80 participações entre exposições, performance, salões de arte. Destacam-se: $32^{\mathrm{a}}$ a $45^{\mathrm{a}}$ Coletiva de Artistas de Joinville, Joinville - SC, 2002 a 2015; Museu da Gravura Cidade de Curitiba - PR, 2015; A Dúvida da Verdade, Badesc, Florianópolis - SC, 2015; BRASILCOLOMBIA/DIGITAL 21. Ink Design, Rio de Janeiro / Casa Proartes, Cali-Chile, 2013; Arte na cidade: entre três espaço-tempo, SESC, Joinville - SC, 2013; 49 Salão Jauense Internacional de Arte Fotográfica, Jaú - SP, 2013; Panorama Santa Catarina SESC, Jaraguá do Sul - SC, 2009 e 2011. Grupo P.S.: $5^{\circ}$ Festival Internacional de Cinema e Direitos Humanos, Montevidéu - Uruguai, 2016. Rumos: Convite à Viagem, Paço Imperial, Rio de Janeiro - RJ, 2013; Convite à Viagem, Itaú Cultural, São Paulo SP, 2012; Volta ao Dia em 80 Mundos, Centro Cultural Octo Marques, Goiânia - GO, 2012; Memorial Meyer Filho, Florianópolis - SC, 2010; Convite projeto ARCADEMIA de Dora Longo Bahia $28^{a}$ Bienal de São Paulo, 2008. Principais Premiações: $1^{\circ}$ Salão dos Novos, MAB, Blumenau - SC, 2002; $10^{\circ}$ Salão Nacional de Arte, Itajaí - SC, 2005; $10^{\circ}$ Salão Nacional Elke Hering, Blumenau - SC, 2012; Elisabete Anderle de Estímulo à Cultura 2014. 